\title{
Alternatives to school sex education
}

\author{
Michael J Reiss
}

\section{Introduction}

School sex education has long been contested in many countries. Disagreements exist about the content of school sex education curricula, including what the term 'sex education' means and therefore what precisely should be covered, the balance that should exist between biology and other subjects, the age at which sex education should start, its pedagogies and its values framework. In addition, a more fundamental point of disagreement is about whether it should take place in schools at all. Sex education is unusual among subjects in that a substantial number of people argue that it should be excluded from school. This chapter therefore looks at what the contributions to sex education might be from a range of sources, principally: school, parents, society in general (e.g. via magazines, films, the internet) and peers.

Sex education is a particularly appropriate subject to consider in a handbook on alternative education for one main reason, namely that it has always been clear that sex education cannot entirely be the responsibility of schools. Even the most enthusiastic believer in the role that schools can play doesn't presume that schools should be responsible for all of sex education; at the very least parents have a role and advocates of school sex education often talk about a partnership between the school and the home.

The role of the school 
What might be the role of the school in sex education and why? As many of the other chapters in this book make clear, and as I will discuss in subsequent sections, there is much that schools don't and can't do that well. However, there are some things that school can do well and should.

For a start, schools employ teachers, i.e. trained professionals used to working with groups of 15 to 30 pupils/students (depending on age). Such professionals should have a number of advantages. In theory they should be experts in their subject and in how to teach it. Immediately we run up against the problem that sex education is not a highly valued subject in the school curriculum. It differs from subjects like mathematics, science and a country's main language as a taught subject both in this respect and because there is less agreement within sex education as to what should be taught and how the subject relates to other subjects (cf. Bernstein, 1996). It is therefore often the case that sex education is taught by teachers with relatively little training in the subject, receives insufficient classroom time and lacks a coherent curriculum.

Nevertheless, there is much that schools can do that is valuable when teaching sex education. For a start, they can prepare a curriculum that takes place over a number of years. Young people often complain that the sex education they receive starts too late (Ofsted, 2013). While there is disagreement as to what precisely falls within the subject of sex education, schools can teach about topics like menstruation to children, say at about age 10, before girls typically start their periods. Similarly, information about sexual intercourse and contraception can be provided to students at about the age of 14 .

Factual information is important but what schools have that parents don't have is a certain emotional distance between the adult and the child. It is not uncommon for parents to report that it is embarrassing for them to teach about sexual intercourse (e.g. Sex Education Forum, 2011). (By co-incidence, as I was writing this section I broke off to have lunch and saw an advertisement for a certain brand of caramel wafer on television that relied on the viewer recognising that it would be 
embarrassing for a father when asked by his daughter 'where do babies come from?'; biting off a chunk of the product bought him time to think how best to answer.) Teachers, of course, may find it embarrassing to teach about such personal matters but they have several advantages over parents. For one thing, they are not as relationally or emotionally close to their students as parents are to their children. (Furthermore, if one accepts a psychoanalytic perspective, parents and their children are likely to find talking about sex difficult in part because of supressed incestual urges that will only partly be avoided by mothers talking with their daughters and fathers with their sons, since, for a girl, talking with her mother is complicated by her unconscious sexual desire for her father; similarly for a boy talking with his father.) Then there is the fact that parents typically only talk to their children about sex a small number of times whereas teachers may do so with several groups in a year and then repeat this year after year. Practice may not make perfect but it does make things easier, less embarrassing and often better.

Another advantage that teachers have over at least some parents when teaching sex education is that they are (or should be) experts not only in terms of subject knowledge but in how to convey that knowledge. Sex education is a subject best taught in a cross-curricular manner, i.e. with aspects of it being addressed in different school subjects, whether or not sex education itself (sometimes combined with other subjects, not just the cognate relationships education but alcohol education and other subjects falling within what is sometimes referred to as personal, social and health education) is taught as a timetabled subject too. So one would expect biology teachers to be good at teaching issues related to such things as puberty (what changes occur, at what age does it typically take place for girls and for boys), how sperm and eggs are produced, how likely sexual intercourse is to result in pregnancy (depending on such factors as the time in the menstrual cycle, the couple's ages, especially that of the woman, factors that result, whether in males or in females, in reduced fertility or infertility), methods of contraception and their efficacy (which depends on the method used and how experienced one is at using it) and sexually transmitted infections (what causes them, how likely one is to catch one, how treatable they are, their effects on fertility and general health). 
This is a fairly conventional list of the things one might expect biology teachers to teach. Nowadays one would hope that biology teachers would also use what we know from science to challenge common stereotypes when this can help students to flourish (Reiss \& White, 2013). For example, school and college biology typically examines issues of human sexuality and femaleness and maleness through the lens of human reproduction. This immediately tends to assume heterosexuality (Reiss, 2007). Biology is all too often presumed to be a largely neutral (i.e. non-value-laden) subject, so that many biology teachers in schools continue to teach biology as unquestioned fact. In particular, differences between females and males are often presented as clear-cut (so that individuals who do not fall neatly into either category are ignored - see Gendered Intelligence http://genderedintelligence.co.uk/) and inevitable, while the study of school biology textbooks shows that they are often sexist and typically ignore lesbian and gay issues (Reiss, 1998). For example, GCSE biology textbooks (i.e. schools books used by 14-16 year-olds) in England often omit all mention of the clitoris and when they do refer to it, frequently talk of it in a belittling way as the female's equivalent of a penis. Males are rendered visible, females less so; and the female exists by virtue of comparison with the male. When homosexuality is addressed, the impression is generally given that it is a sort-of second-best option which the reader may well grow out of. However, closer examination of sex in human biology provides plenty of space for critical reflection and allows for a richer understanding of what it is to be a sexual person.

Emily Martin argued that while menstruation is viewed in scientific textbooks as a failure (you should have got pregnant), sperm maturation is viewed as a wonderful achievement in which countless millions of sperm are manufactured each day (Martin, 1991). Furthermore, sperm are viewed as active and streamlined whereas the egg is large and passive and just drifts along or sits there waiting. It was back in 1948 that Ruth Herschberger argued that the female reproductive organs (it is difficult in the scientific discourse around sex to avoid referring to reproduction unless one uses the term 'urino-genital organs', which doesn't sound much better) are viewed as somehow being less autonomous than those of the male. The way the 
egg is portrayed in science textbooks has been likened to that of the fairy tale Sleeping Beauty, in which a dormant, virginal bride awaits a male's magic kiss. However, for well over a decade biologists have seen both egg and sperm as active partners. Just as sperm seek out the egg, so the vagina discriminates between sperm, and the egg seeks out sperm to catch. Nevertheless, as Martin points out, even when acknowledged, such biological equality is still generally described in a language that gives precedence to the sperm. When the egg is presented in an active role, the image is one of a dangerous aggressor "rather like a spider laying in wait in her web" (Martin, 1991, p.498).

Social historical research on sex hormones has also shown how the way that such hormones are presented in textbooks and scientific papers gives messages that go well beyond what the data indicate. Despite the fact that it has been known since the 1920s that each sex contains the 'other's' hormone - i.e. males contain oestrogen and females testosterone - school textbooks typically ignore both this fact and the close chemical similarity between oestrogen and testosterone (Roberts, 2002). Indeed, a different reading of the data to that usually presented in school textbooks - but one more in line with the scientific evidence about the working of sex hormones - is that femaleness and maleness lie on a continuum. Such a model of the consequences of the actions of the sex hormones became common among academic endocrinologists (who study hormones) from the 1940s. While this model can lead to an essentialist understanding of sexuality and sexual orientation - and is correlated with a rise in the number of studies of the presumed femininity of gay men (Oudshoorn, 1994) - it can also be seen as allowing a far more fluid understanding of sexuality, accommodating, for example, some forms of intersexuality.

The principle of intersexuality dates largely from Magnus Hirschfeld's pioneering work in the first three decades of the twentieth century on sexual difference. By rejecting the discrete categories of male and female, arguing instead that each of us uniquely sits on a continuum, Hirschfeld did not so much give rise to the notion of 'the third sex' as radically deconstruct the sexual binary (Bauer, 2003). 
Biological indicators of sexual orientation have long been sought and continue to fascinate commentators, while worrying many in the gay and lesbian communities. Hardly a month goes by without a report of some such biological indicator. Precisely which indicator is flavour of the month (a hormone, a gene, parental upbringing, relative finger length, etc.) may tell us more about research fashions than much else. Around the middle of the twentieth century, hormones were widely thought to be all powerful and responsible for our sexuality. Hormones are chemicals made in glands; they then circulate in the body and reach target organs where they have their effects. Towards the end of the twentieth century the focus shifted to genes, the building blocks of our chromosomes. Genes are responsible for the chemicals, including hormones, made in the body and a reductionist perspective sees them as determining not just sex and sexuality but almost all of what it is to be ourselves.

Much of the literature about the 'causes' of sexuality concentrates on gayness, though Lynda Birke, a biologist as well as a feminist and a lesbian, provides a valuable review about lesbianism and over the years has "spent much time and energy refuting the allegations that any social categories (of gender, race or sexuality) are fixed by biology" (Birke, 1997, p.58). However, as Birke points out, there are, of course, a number of reasons for hesitating in rejecting entirely biological notions of sexual orientation. For one thing, some have used such notions politically to argue for gay rights (though this approach is hotly contested - see Schüklenk and Brookey, 1998); more prosaically, it may well yet turn out that there is / are biological bases to at least some people's sexuality.

All of which leads one to ask how might biology be taught better in schools. Much biology teaching is focused around the use of textbooks which all too often are consumed uncritically by teachers and students alike. Yet "Teachers can read subtextually and resistantly and can help their students to do likewise. Too rarely are students encouraged to critique their science textbooks; too often are textbooks used as if they contained only unquestionable truths" (Reiss, 1998, p.148). This is a simple message but one that provides a teacher - and her/his students - with a 
powerful tool, for it avoids buying into the general assumption of teacher as the expert repository of facts, instead sitting more comfortably with emancipatory understandings of education. This is more satisfying for teacher and students alike and fits well with an information society which proves students with plenty of opportunities to obtain many of the facts they want/need to know at the right pace for themselves.

Of course, for anyone, including teachers, to change their practice is rarely straightforward. The literature on continuing professional development and teacher change shows that a whole range of factors are needed (Loucks-Horsley et al., 2003; Owen, 2015), otherwise even the best of intentions is unlikely to be embedded in subsequent practice.

An account of what biology teachers can do in relation to sex education is provided by Anne-Marie Scholer in her published description of her teaching programme for a two-semester intermediate-level college course in anatomy and physiology, required for first-year students in nursing, athletic training and physical therapy majors (Scholer, 2002). Scholer begins with the idea that male/female is not a dichotomy. Here she draws on the various causes of indeterminate gender in humans, the sex hormone story outlined above, the existence of breast cancer in men, and the occurrence of transgender. As she says, "While the foregoing material is undoubtedly familiar to individuals in the fields of sexuality education, it is quite new to most of my students and peers. I have found such examples to work well in class, creating vocal displays of cognitive dissonance" (Scholer, 2002, p.78). As every teacher knows, cognitive dissonance, if well handled, can be a powerful incentive to learning. (Handled badly it can merely reinforce prejudice or be rejected as confusing.) Scholer goes on to challenge the prevailing stereotype of eggs as passive objects, to discuss how sex is not just anatomy and hormones, to avoid heteronormativity and generally to "create an inclusive environment in my classroom" (p.82). 
I have spent some time on the possible contribution of biology teachers in schools as sex education, certainly once students have reached the age where they have specialist subject teachers, is often seen as entirely or largely being the responsibility of biology teachers. However, other subjects can and should make a major contribution too. Indeed, young people often complain that the sex education they receive is 'too biological' (Brook, PSHE Association and Sex Education Forum, 2014) with insufficient time and attention being paid to issues to do with relationships. These can be dealt with in biology but often come up naturally in other subjects, including lessons on literature - one can hardly read many great works of literature without finding issues to do with relationships, including love and sex, addressed. Geography, History and Religious Education are other subjects that typically include material that falls under the umbrella of sex education.

In my experience, a particularly valuable role that schools can play in teaching about sex education is discussions and role plays facilitated by a teacher. One is in a very unusual position as a teacher. One can require pupils/students to discuss and act issues that they wouldn't do outside of school. Discussion / role plays about such issues as whether clothing should be gender specific, what is acceptable behaviour on a first, second or nth date, how one would feel if one's younger sib came out as gay/lesbian, whether one wants to have children and if so how many can all be valuable.

\section{The role of parents}

Other chapters in this book discuss issues to do with home schooling and the role of parents in education (cf. Lees, 2014). For sex education, though, parents have always played a special role. Even organisations passionate about school sex education envisage sex education as a partnership between the school and the home in a way that is rare or non-existent in other subjects which, aside from reading with young children, are mostly content for parents simply to oversee homework and provide a 
range of extra-curricular activities (swimming, visits to museums and art galleries, etc.).

Actually, I suspect that some organisations that advocate a role for parents in sex education do so largely for political reasons, because they see the threat to school sex education (e.g. from organisations in the UK such as the Society for the Protection of Unborn Children https://www.spuc.org.uk/campaigns/safeatschool/ and the Family Education Trust http://www.famyouth.org.uk/) as best countered by an endorsement of school-parent partnerships. That aside, parents would seem to have a special role in the provision of sex education for a number of reasons.

First of all, parents nearly always know their children well. If we simply take something within sex education as relatively uncontroversial as puberty, the age at which a child enters puberty varies greatly, meaning that leaving the issue to schools means that education is inevitably provided too late for some (potentially alarming and embarrassing, particularly for girls) and too early for others (which is not good educational practice).

Then there is the fact that parents may have values that differ from those of the school(s) to which their child(ren) would go. There are values associated with all school subjects but not equally; sex education is a subject where values are of particular importance (Halstead \& Reiss, 2003). Of particular significance for sex education are religious values (Reiss, 2014). For some people, their religious faith is absolutely the core of their being: they could no more feel comfortable acting or thinking in a way that conflicted with their religious values than they could feel comfortable not breathing. Other ways of expressing this are to say that their worldview is a religious one or that religion plays a central part in their identity. For other people, religious faith is either an irrelevancy - an historical anachronism - or positively harmful, with many of the ills that befall humankind being placed at its door. 
The first major attempt in the UK among believers from a number of religious traditions to agree a religious perspective on sex education resulted in an agreed statement by members of six major UK religions (Islamic Academy, 1991). This statement provided a critique of contemporary sex education, listed principles which it was felt ought to govern sex education and provided a moral framework for sex education. This framework 'Enjoins chastity and virginity before marriage and faithfulness and loyalty within marriage and prohibits extramarital sex and homosexual acts', 'Upholds the responsibilities and values of parenthood', 'Acknowledges that we owe a duty of respect and obedience to parents and have a responsibility to care for them in their old age and infirmity' and 'Affirms that the married relationship involves respect and love' (Islamic Academy, 1991, p.8).

Another early UK project to look at the important of religion and ethnicity for sex education was the Sex Education Forum's 'religion and ethnicity project'. A working group was set up which "was concerned to challenge the view that religions offer only negative messages around sex, wanting to explore the broader philosophy and rationale behind specific religious prescriptions" (Thomson, 1993, p.2). Each participant was sent a total of 28 questions (e.g. 'Are there different natural roles for men and women, if so why?' and 'What is the religious attitude towards contraception and/or 'protection' for example, safe sex re: STDs, HIV?') and the project chose to present a range of views, rather than attempting to reach a consensus.

At the same time as Rachel Thomson was compiling her pack, Gill Lenderyou and Mary Porter of the Family Planning Association were putting together a booklet arising from the 'Values, faith and sex education' project (Lenderyou \& Porter, 1994). At a four-day residential event in this project, a bill of pupils' rights was drawn up by 22 people of different religious faiths, and agreed statements on sex education were produced under the headings of: Respect and difference, Faith and change in society, Male and female equality, Relationships and marriages, Homosexuality, Cohabitation, Disability and sexuality, and Celibacy. The bill of pupils' rights is more liberal and the agreed statements are more tentative than the contents of the 
Islamic Academy (1991). For example, included in the bill of pupils' rights are the assertions that pupils have the right to sex education that 'Provides full, accurate and objective information about growth and reproduction on topics including puberty, parenthood, contraception, child care and responsible parenthood' and that pupils have the right 'To be consulted about the manner in which sex education is implemented in the classroom in connection with issues such as whether it takes place in single sex or mixed groups or which topics can be included in the programme' (Lenderyou \& Porter 1994, p.37).

Subsequently, Shaikh Abdul Mabud and I edited an academic book titled Sex Education and Religion which concentrated on Christian and Muslim views about sex education (Reiss \& Mabud, 1998), and publications resulted from projects funded by the Department of Health's former Teenage Pregnancy Unit including 'Supporting the Development of SRE (sex and relationships education) within a Religious and Faith Context' (Blake \& Katrak, 2002). Since that time, an increasing number of publications have considered the importance of religion for sex education (e.g. Rasmussen, 2010; Smerecnik et al., 2010).

Of course, the fact that religion is important for many parents doesn't necessarily mean that parents have a right to impose their religious values on their children, whether in respect of sex education or anything else, but nor is it the case that parents are forbidden from attempting to influence their children's sexual behaviour when they feel that what they (the parents) are advocating is what is best for their children. As is so often the case, appeals to 'rights' do not settle the issue at hand; rights can conflict and then some mechanism needs to be used to decide amongst them. Ramaekers and Suissa (2012) explore the complexities of parenthood at a time of increasing government intervention in family life, while Brighouse and Swift (2014) maintain that "parents' rights over their children are justified by appeal to children's rather than parents' interests" (p.18).

Furthermore, religions do not speak with one voice in respect of sex education, though this is less the case for some religions (e.g. Islam) than others (e.g. Judaism 
(Fader, 2009) and Christianity). Feminism and liberalism, in particular, have had less influence among Islamic than Christian theology and educational theory.

\section{Autodidactism}

Autodidactism has a long history (Solomon, 2003). I imagine if most of us as adults think back as to how we learnt most about sex and relationships, it wasn't from school or our parents, beyond perhaps some specifics we may have learnt at school and, hopefully, an ethos of respect for others from our parents; it was from our own, personal 'university of life' - an instance of autodidactism. One can learn a certain amount about car driving without actually getting into a car but the most important learning comes when one is behind the wheel. Similarly, surely most of us learn most about sex and relationships from our own attempts to relate to others, to strike up friendships, sometimes in the hope that one or other might develop into a sexual relationship.

One doesn't need to be an evolutionary biologist to realise that the urge to enjoy sexual intercourse can be one of the most powerful drives most of us can experience - and sexual activity is more than sexual intercourse. For the great majority, perhaps all, non-human animals, sexual activity is very largely or entirely automatic. Humans, of course, are distinctive in that we still have the urges that other animals have (whether sexual or to do with eating, relating to others and all the other aspects of our behaviour) but we have a mind capable of reflection and (on a good day) rational thought. Some of us may give little thought to our sexual behaviour but most of us, perhaps especially when we are young and at the start of a new, potentially sexual, relationship, agonise over it. Our sexual behaviour can be acutely embarrassing or feel like the most wonderful thing we have ever ben involved in. As I once wrote in a piece about sex education and spirituality education:

There are certain things that it is better to learn for oneself - better in the senses of more authentic, more valid and more memorable. So where might 
these aspects to sex education and spirituality education that I suspect should not, or cannot, be learnt about in schools best be learnt? Surely in situ. The fullest way to learn about a marriage is in marriage; the fullest way to learn about the Eucharist is in receiving communion; the fullest way to learn about sexual intercourse is with one other person in private. Other learning can be preparatory - schools can help pupils to develop commitment, be true to themselves and to others, to manifest forgiveness and so on - but the fullest learning in these areas is ultimately that which is authentic and truly participatory. And the language of such learning is rarely the language of words but, whether we are talking about sex education or education about spirituality, the language of imagination, of experience, of touch and of the other senses. (Reiss, 2001, pp.244-5)

\section{Peers, the media and the internet}

Finally, there are other sex education influences in addition to one's parents, one's school and what one chooses to learn oneself. One's peers are important for much of one's learning and this is particularly true for sex education; surveys show that peers are cited as one of the most important sources of information for young people about sex (Bleakley et al., 2009). At the same time, attempts to involve peers in school sex education programmes have not been particularly successful (Stephenson et al., 2004).

The media have become more important as sexuality has become more 'plastic' (Giddens, 1992), i.e. as sexuality has become freed from its intrinsic relation to reproduction. Newspapers, magazines, films and other media all contribute to manufacturing an account of what is or is not expected of one in terms of sexual knowledge and behaviour as one grows up. In recent years, the surge in internet accessibility has meant that access to pornography, including pornography that is increasingly degrading to women, has become more prevalent and to boys of a much younger age than used to be the case. At the same time, the use of mobile 
technologies has meant that new forms of bullying (notably cyberbullying and sexting) have become widespread (cf. Ringrose, 2013). Legislators are struggling to keep up - though recent bans on so-called 'revenge porn' in a number of jurisdictions indicate that conventional legislation does have a role to play along with action by social media sites.

While the internet can be threatening it can also be a site for valid sex education. An increasing number of such sites exist (e.g. Sex, Etc. | Sex education by teens, for teens http://sexetc.org/, Scarleteen | Sex Education For The Real World www.scarleteen.com/, Dr Triece Turnbull's Parent Zone www.parent-zone.com/). Green et al. (2015) discuss how popular sex education teaching methods (including brainstorming, demonstrations, videos, films and role plays) can be successfully translated into online learning environments. It's probably too early to be confident how valuable such sites are. Some may worry that they are only a few clicks away from harmful pornography but then so is everything on the internet, including videos of cute cats. More positively, through a process akin to natural selection, the algorithms employed by search engines favour sites that are accessed most often and, by and large, this will be because they are providing what viewers want. The best such sites offer accurate, up-to-date information, something akin to agony aunts and facilitated discussion, all at a level the viewer wants and without anyone seeing one get tongue-tied or embarrassed.

Unsurprisingly, internet pornography has led to changes in books about sex education:

Ann-Marlene Henning's Sex and Lovers: a practical guide has been described as The Joy of Sex for the new generation. But while the 1970s manual famously had line drawings of naked-yet-hirsute lovers, Henning's book includes photographs of real-life sexual partners having real-life sex.

Though artfully shot, and largely involving young, attractive people, the photos are unquestionably explicit. As well as full and oral sex, there are 
photos of gay couples: a woman sucking on her girlfriend's breast; two men kissing.

"They're just having normal sex - that's is," Ms Henning, a Danish neuropsychologist who now practices as a sexologist in Germany, says of the photos. "We need pictures like that. All that internet porn stuff is too rough, too fast, and just strange-looking people. Too much, too much." (Bloom, 2014, p.18)

\section{Conclusions}

For most of us, who we are and how we understand ourselves sexually is of great personal significance. This is especially true for most young people as they grow up. Done well, sex education can make a major contribution to human flourishing; done badly it can be positively harmful. Schools do have a role to play in the sex education that young people should receive. This is in large measure by virtue of a number of respects in which teachers differ from parents (and others) in terms of their pedagogical expertise and their relationships with their students. However, schools cannot on their own provide young people with all the sex education that they need. This has probably always been the case. Parents and other out-of-school sources have a vital role to play. In all cases, those providing sex education should strive to do so in a way that is in the best interests of those whom they are seeking to educate.

\section{References}

Bauer, J. E. (2003) Magnus Hirschfeld's doctrine of sexual intermediaries and the transgender politics of identity. Paper given at the Conference: Past and Present of Radical Sexual Politics, Amsterdam, 3-4 October, 2003. Available at www.iisg.nl/ womhist/hirschfeld.doc. (Last accessed 15 February 2015.) 
Bernstein, B. (1996) Pedagogy, Symbolic Cobntrol and Identity: Theory, Research, Critique, revised edn, Lanham: Rowman \& Littlefield.

Birke, L. (1997) Born queer? Lesbians interrogate biology, in: Straight Studies Modified: Lesbian Interventions in the Academy, Griffin, G. \& Andermahr, S. (Eds), London: Cassell, pp.57-70.

Blake, S. \& Katrak, Z. (2002). Faith, Values and Sex \& Relationships Education, London: National Children's Bureau.

Bleakley, A., Hennessy, M., Fishbein, M. \& Jordan, A. (2009). How sources of sexual information relate to adolescents' beliefs about sex, American Journal of Health Behavior, 33(1), 37-48.

Bloom, A. (2014) 'They're just having normal sex. Why can't I show it?' Author of explicit book says adult shame stops frank lessons, TES, 7 November, 18-19.

Brighouse, H. \& Swift, A. (2014) Family Values: The Ethics of Parent-child Relationships, Princeton: Princeton University Press.

Brook, PSHE Association and Sex Education Forum (2014) Sex and Relationships Education (SRE) for the 21st Century. Available at http://www.sexeducationforum.org.uk/media/17706/sreadvice.pdf.

Fader, A. (2009) Mitzvah Girls: Bringing up the Next Generation of Hasidic Jews in Brooklyn, Princeton: Princeton University Press.

Giddens, A. (1992) The Transformation of Intimacy: Sexuality, Love and Eroticism in Modern Societies, Cambridge: Polity Press.

Green, E. R., Hamarman, A. M. \& McKee, R. W. (2015) Online sexuality education pedagogy: translating five in-person teaching methods to online learning environments, Sex Education, 15, 19-30.

Halstead, J. M. \& Reiss, M. J. (2003) Values in Sex Education: From Principles to Practice, London: RoutledgeFalmer.

Islamic Academy (1991). Sex Education in the School Curriculum: The Religious Perspective - an agreed statement, Cambridge: The Islamic Academy.

Lees, H. E. (2014) Education Without Schools: Discovering Alternatives, Bristol: Policy Press.

Lenderyou, G. \& Porter, M. (Eds) (1994). Sex Education, Values and Morality, London: Health Education Authority. 
Loucks-Horsley, S., Love, N., Stiles, K. E., Mundry, S. \& Hewson, P.W. (2003)

Designing Professional Development for Teachers of Science and Mathematics, $2^{\text {nd }}$ edn, Thousand Oaks, CA: Corwin Press.

Martin, E. (1991) The egg and the sperm: how science has constructed a romance based on stereotypical male-female roles, Signs: Journal of Women in Culture and Society, 16, 485-501.

Ofsted (2013) Not Yet Good Enough: Personal, Social, Health and Economic Education in Schools, Ofsted, Manchester. Available at https://www.gov.uk/government/uploads/system/uploads/attachment data/file $\$ 370027 /$ Not yet good enough personal social health and economic educ ation in schools.pdf.

Oudshoorn, N. (1994) Beyond the Natural Body: An Archeology of Sex Hormones, London: Routledge.

Owen, S. M. (2015) Teacher professional learning communities in innovative contexts: 'ah hah moments', 'passion' and 'making a difference' for student learning, Professional Development in Education, 41, 57-74.

Ramaekers, S. \& Suissa, J. (2012) The Claims of Parenting: Reasons, Responsibility and Society, Springer, Dordrecht.

Rasmussen, M. L. (2010) Secularism, religion and 'progressive' sex education, Sexualities, 13, 699-712.

Reiss, M. J. (1998) The representation of human sexuality in some science textbooks for 14-16 year-olds, Research in Science \& Technological Education, 16, 137-149.

Reiss, M. J. (2001) Loves that have a quiet voice, International Journal of Children's Spirituality, 6, 243-245.

Reiss, M. (2007) Representing the world: difference and science education. In: Marginality and Difference In Education and Beyond, Reiss, M., DePalma, R. \& Atkinson, E. (Eds), Stoke-on-Trent: Trentham, pp.61-72.

Reiss, M. J. (2014) Sex education and science education in faith-based schools. In: International Handbook of Learning, Teaching and Leading in Faith-Based Schools, Chapman, J. D., McNamara, S., Reiss, M. J. \& Waghid, Y. (Eds), Dordrecht: Springer, pp.261-276. 
Reiss, M. J. \& Mabud, S. A. (Eds) (1998) Sex Education and Religion, Cambridge: The Islamic Academy.

Reiss, M. J. \& White, J. (2013) An Aims-based Curriculum: The Significance of Human Flourishing for Schools, London: IOE Press.

Ringrose, J. (2013) Postfeminist Education? Girls and the Sexual Politics of Schooling, Routledge, Abingdon.

Roberts, C. (2002) 'A matter of embodied fact': sex hormones and the history of bodies, Feminist Theory, 3, 7-26.

Scholer, A.-M. (2002) Sexuality in the science classroom: one teacher's methods in a college biology course, Sex Education, 2, 75-86.

Schüklenk, U. and Brookey, R. A. (1998) Biomedical research on sexual orientation: researchers taking our chances in homophobic societies, Journal of the Gay and Lesbian Medical Association 2(2), 79-84.

Sex Education Forum (2011) Parents and SRE: A Sex Education Forum Evidence Briefing, National Children's Bureau, London. Available at http://www.ncb.org.uk/media/333401/parents sre.pdf.

Smerecnik, C., Schaalma, H., Gerjo, K., Meijer, S., \& Poelman, J. (2010). An exploratory study of Muslim adolescents' views on sexuality: implications for sex education and prevention, BMC Public Health, 10, 533.

Solomon, J. (Ed.) (2003) The Passion to Learn: An Inquiry into Autodidactism, London: RoutledgeFalmer.

Stephenson, J. M., Strange, V., Forrest, S., Oakley, A., Copas, A., Allen, E., Babiker, A., Black, S., Ali, M., Monteiro, H. \& Johnson, A. M. (2004) Pupil-led sex education in England (RIPPLE study): cluster-randomised intervention trial, The Lancet, 364 (9431), 338-346.

Thomson, R. (Ed.) (1993). Religion, Ethnicity \& Sex education: Exploring the Issues - a resource for teachers and others working with young people. London: National Children's Bureau. 